\title{
Nitrification Inhibitor 3,4-dimethylpyrazole Phosphate Improves Nitrogen Recovery and Accumulation in Cotton Plants by Reducing NO3- Leaching Under $15 \mathrm{~N}$-urea Fertilization
}

\section{Ezio Nalin de Paulo}

University of São Paulo, Center for Nuclear Energy in Agriculture, Piracicaba, 13416-000, Brazil

\section{Fernando Shintate Galindo}

University of São Paulo, Center for Nuclear Energy in Agriculture, Piracicaba, 13416-000, Brazil

Flávio Henrique Silveira Rabêlo

University of São Paulo, College of Agriculture Luiz de Queiroz, Piracicaba, 13418-900, Brazil. Joaquim José Frazão

University of São Paulo, Center for Nuclear Energy in Agriculture, Piracicaba, 13416-000, Brazil Jose Lavres ( $\square$ jlavres@cena.usp.br)

University of São Paulo, Center for Nuclear Energy in Agriculture, Piracicaba, 13416-000, Brazil https://orcid.org/0000-0002-7183-4008

\section{Research Article}

Keywords: Gossypium hirsutum L., 15N isotope, nitrate leaching, urea, DMPP, fate of nitrogen

Posted Date: March 10th, 2021

DOl: https://doi.org/10.21203/rs.3.rs-297839/v1

License: (c) (1) This work is licensed under a Creative Commons Attribution 4.0 International License.

Read Full License

Version of Record: A version of this preprint was published at Plant and Soil on October 1st, 2021. See the published version at https://doi.org/10.1007/s11104-021-05169-4. 
Nitrification inhibitor 3,4-dimethylpyrazole phosphate improves nitrogen recovery and accumulation in cotton plants by reducing $\mathrm{NO}_{3}{ }^{-}$leaching under ${ }^{15} \mathrm{~N}$-urea fertilization

\section{Ezio Nalin de Paulo ${ }^{\mathrm{a}}$, Fernando Shintate Galindo ${ }^{\mathrm{a}}$, Flávio Henrique Silveira Rabêlo ${ }^{\mathrm{b}}$, Joaquim} José Frazão ${ }^{\mathrm{a}}$, José Lavres ${ }^{\mathrm{a}, *}$

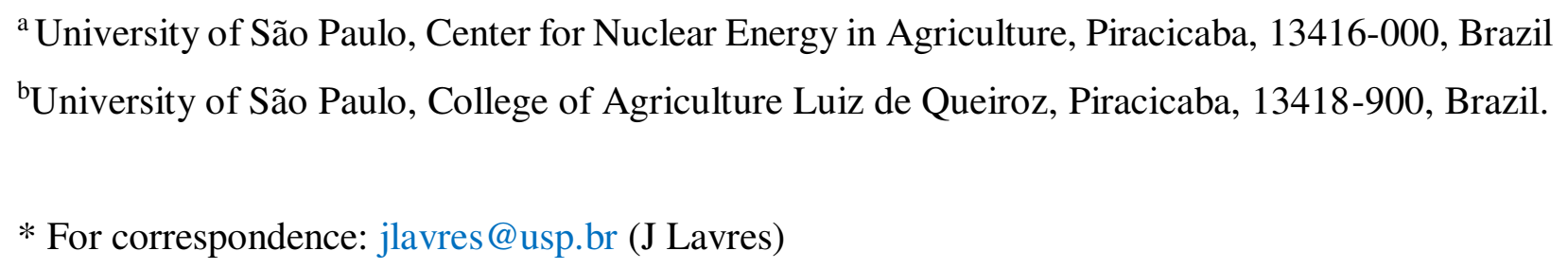

Date of submission: March X, 2021

Word count: 6,731

Figure: 4

\section{Acknowledgments}

JL thanks the "National Council for Scientific and Technological Development" of Brazil (“Conselho Nacional de Desenvolvimento Científico e Tecnológico - CNPq") for the research fellowship (Grant number 310572/2017-7). This study was financed in part by the "Coordenação de Aperfeiçoamento de Pessoal de Nível Superior - Brasil (CAPES)” - Finance Code 001. 


\section{Declarations}

26

27 Funding: We are thankful to the "National Council for Scientific and Technological 28 Development” of Brazil ("Conselho Nacional de Desenvolvimento Científico e Tecnológico 29 CNPq") for the research fellowship (Grant number 310572/2017-7). This study was financed in 30 part by the "Coordenação de Aperfeiçoamento de Pessoal de Nível Superior - Brasil (CAPES)" 31 Finance Code 001.

32

33 Conflicts of interest/Competing interests: None.

34

Availability of data and material: Not applicable.

36

37

Ethics and Legal Compliance: The research does not involve humans and animals in the 38 experimental part. 

accumulation in cotton plants by reducing $\mathrm{NO}_{3}^{-}$leaching under ${ }^{15} \mathrm{~N}$-urea fertilization

\section{Abstract}

Purpose: The use of nitrification inhibitors could be an interesting alternative to enhance nitrogen (N) fertilizer use efficiency in annual crops such as cotton, under tropical soil conditions. Thus, our aim was to evaluate the efficiency of nitrification inhibitor 3,4-dimethylpyrazole phosphate (DMPP) in a typical tropical soil, evaluating the fate of nitrogen $\left(\mathrm{N}-\mathrm{NO}_{3}{ }^{-}, \mathrm{N}-\mathrm{NH}_{4}{ }^{+}\right.$and total $\mathrm{N}$ in soil and leached water), $\mathrm{N}$-accumulation and $\mathrm{N}$ recovery by cotton plants and soil. Methods: Leaching columns with cotton plants were used to access $\mathrm{N}_{-} \mathrm{NO}_{3}{ }^{-}$and $\mathrm{N}_{-} \mathrm{NH}_{4}{ }^{+}$losses in drainage water. Treatments consisted in three $\mathrm{N}$ levels applied in side-dressing (corresponding to 50, 100 and $150 \mathrm{~kg} \mathrm{~N} \mathrm{ha}^{-1}$ ) as ${ }^{15} \mathrm{~N}$-urea with and without DMPP application. An additional treatment (absence of $\mathrm{N}$ application in side-dressing) was used as control. Results: 3,4-dimethylpyrazole phosphate was efficient to improve $\mathrm{N}$ recovery from applied urea fertilizer in plants and in the soil by reducing $\mathrm{NO}_{3}{ }^{-}$leaching, leading to enhanced $\mathrm{N}$ acquisition from fertilizer and soil, augmenting plants $\mathrm{N}$-accumulation, mainly when high $\mathrm{N}$ levels above $100 \mathrm{~kg} \mathrm{~N} \mathrm{ha}^{-1}$ were applied. We found that total $\mathrm{N}$ recovery increased $31 \%$ when $150 \mathrm{~kg} \mathrm{~N} \mathrm{ha}^{-1}$ was applied as urea + DMPP source compared to conventional urea. In addition, DMPP application reduced $\mathrm{NO}_{3}{ }^{-}$leaching losses (c.a. of 11 to 20\%), although had no significant effect on shoot and root dry matter yield. Conclusion: The reduction of $\mathrm{NO}_{3}{ }^{-}$leaching losses highlights the potential of DMPP to mitigate the impact of

75 increased urea input on leaching losses thereby improving $\mathrm{N}$ use efficiency and $\mathrm{N}$ uptake in cotton crop.

Keywords: Gossypium hirsutum L., ${ }^{15} \mathrm{~N}$ isotope, nitrate leaching, urea, DMPP, fate of nitrogen 


\section{Introduction}

Cotton (Gossypium hirsutum L.) is a tropical crop and plays a significant role in the economic development worldwide, being an important source of fiber, oil, and animal feed (Shah et al., 2017; Khan et al., 2017a, 2017b). Nitrogen (N) is the nutrient most required for cotton production (Luo et al., 2018). It has been reported that cotton plants have high $\mathrm{N}$ demands ranging from 50 to $412 \mathrm{~kg} \mathrm{~N}^{-1}$ (Khan et al., 2017c; Zurweller et al., 2019).

Nitrogen application can enhance photosynthesis, canopy area, lint yield, fiber quality and resistance to harsh environmental conditions such as drought and salinity (Luo et al., 2018; Zurweller et al., 2019). Globally, more than 90 million metric tons of nitrogenous fertilizers are applied to the soil every year, 50 to $70 \%$ of which are lost and only a small fraction are absorbed by the plants (Khan et al., 2017c). Consequently, $\mathrm{N}$ fertilizer is often applied excessively in cotton producing regions (Luo et al., 2018). Thus, $\mathrm{N}$ management is one of the most fundamental aspects of cotton production (Shah et al., 2017; Bronson et al., 2018).

Low or excessive $\mathrm{N}$ application levels can impair plant development, cotton yield, nitrogen use efficiency (NUE) and plant $\mathrm{N}$ recovery ( $\mathrm{N}$ recovery) (Li et al., 2017; Khan et al., 2017c). Countless factors are related to optimum $\mathrm{N}$ management, such as soil texture and fertility levels, yield potential, and crop management practices (Khan et al., 2017c). In addition, N-fertilizer uptake and utilization is positively related to both dry matter yield and crop canopy (Dai and Dong, 2014).

Exhaustive N-fertilizers application negative affects plant ecosystems and biodiversity, leading to environmental pollution (Yang et al., 2013). The recovery of $\mathrm{N}$-fertilizer by annual crops is typically low, usually ranging between 30 to $50 \%$ of applied N (Herrera et al., 2016), with less than $10 \%$ of the residual $\mathrm{N}$ recovered in subsequent cropping seasons (Khan et al., 2017c). The $\mathrm{N}$ losses from fertilizer in agricultural systems in gaseous forms including nitrous oxide $\left(\mathrm{N}_{2} \mathrm{O}\right)$, ammonia $\left(\mathrm{NH}_{3}\right)$ and molecular nitrogen $\left(\mathrm{N}_{2}\right)$ or as nitrate $\left(\mathrm{NO}_{3}{ }^{-}\right)$represent a substantial loss of resource investment to farmers (Friedl et al., 2017; Rose et al., 2018). Environmental consequences include greenhouse gas emissions $\left(\mathrm{N}_{2} \mathrm{O}\right)$, eutrophication of waterways (deposition of $\mathrm{NH}_{4}{ }^{+}$and leaching of $\mathrm{NO}_{3}{ }^{-}$), and ozone depletion $\left(\mathrm{N}_{2} \mathrm{O}\right)$ (Huang et al., 2017; Rose et al., 2018; Gong et al., 2019).

The world population has been growing swiftly, while global fiber production has increased driven to environmental problems related to more reactive $\mathrm{N}$ in soil, water and air (Khan 
115

116

117

118

119

120

121

122

123

124

125

126

127

128

129

130

131

132

133

134

135

136

137

138

139

140

141

142

143

144

145

et al., 2017c). Improving $\mathrm{N}$ utilization in agricultural production systems is mandatory to avoid environmental risks and economic losses (Li et al., 2017; Zurweller et al., 2018). Consequently, $\mathrm{N}$ fertilizers should be used more efficiently in modern agriculture (Galindo et al., 2021a).

Considering the limited recovery of applied $\mathrm{N}$ fertilizers by agricultural crops, the use of enhanced-efficiency $\mathrm{N}$ fertilizers (EENF) has been widely increasing (Rose et al., 2018). Enhanced-efficiency $\mathrm{N}$ fertilizers have different modes of action that control the rate of $\mathrm{N}$ release or $\mathrm{N}$ availability from the $\mathrm{N}$-fertilizer source to the crop (Halvorson et al., 2014). One of the most studied and applied group of EENF is the nitrification inhibitor, highlighting 3,4-dimethylpyrazole phosphate (DMPP) (Rose et al., 2018).

The DMPP is related to delay the oxidation of $\mathrm{NH}_{4}{ }^{+}$to $\mathrm{NO}_{3}{ }^{-}$thereby preventing $\mathrm{N}$ losses through nitrification and denitrification (Shi et al., 2016; Luchibia et al., 2020; Qiao et al., 2021). This delay maintains the applied $\mathrm{N}$ fertilizer in the less mobile form of $\mathrm{NH}_{4}{ }^{+}$, limiting the buildup of mobile $\mathrm{NO}_{3}{ }^{-}$in the soil (Friedl., et al., 2017; Padilla et al., 2018). The reduction of nitrous oxide $\left(\mathrm{N}_{2} \mathrm{O}\right)$ emissions provided by DMPP application is therefore attributed to reduced nitrification rates and a reduced $\mathrm{NO}_{3}{ }^{-}$pool available for denitrification (Ruser and Schulz, 2015; Suter et al., 2020).

Recent reviews have concluded that the use of nitrification inhibitors can significantly decrease soil $\mathrm{N}_{2} \mathrm{O}$ emissions in upland (i.e. non-flooded) crops compared to conventional $\mathrm{N}$ fertilizer sources (Ruser and Schulz, 2015; Padilla et al., 2018; Rose et al., 2018; Huérfano et al., 2019). Meta-analysis studies concluded that DMPP application could decrease $\mathrm{N}_{2} \mathrm{O}$ emission by 38 to $42 \%$ (Akiyama et al., 2010; Gilsanz et al., 2016). While meta-analyses broadly suggest that nitrification inhibitors can decrease $\mathrm{N}_{2} \mathrm{O}$ emissions, the effect of DMPP on nitrate leaching losses and $\mathrm{N}$ recovery is less noticeable.

We hypothesized with this study that DMPP application would improve $\mathrm{N}$ recovery from applied $\mathrm{N}$ levels by reducing $\mathrm{N}$ losses from $\mathrm{NO}_{3}{ }^{-}$leaching, leading to a greater $\mathrm{N}$-accumulation in cotton plants, benefiting plant development and biomass yield. Thus, our aim with this study was to gain better understand on how DMPP would affect the fate of $\mathrm{N}$ (mainly $\mathrm{N}-\mathrm{NO}_{3}{ }^{-}$and $\mathrm{N}-\mathrm{NH}_{4}{ }^{+}$)in soil, plant and leached water and could influence $\mathrm{N}$ recovery and cotton growth. Isotopic techniques $\left({ }^{15} \mathrm{~N}\right)$ were used to access the quantity of $\mathrm{N}$ derived from fertilizer (NDF), soil and other sources (NDS), as well as to evaluate $\mathrm{N}$ recovery in plant and soil. 


\section{Material and Methods}

\section{Growth conditions}

The study was carried out in a greenhouse with controlled conditions (the temperature in the greenhouse during plant growth ranged between $25.9{ }^{\circ} \mathrm{C}$ (minimum) and $33.6^{\circ} \mathrm{C}$ (maximum), and averaged $30.1{ }^{\circ} \mathrm{C}$. The average air relative humidity was $65 \% \pm 5 \%$, and the maximum photosynthetic photon flux density (sunlight) was approximately $1600 \mu \mathrm{mol}$ photons $\mathrm{m}^{-2} \mathrm{~s}^{-1}$ at the leaf level delivered by LED lamps 18 W 840 T8C W G,), by using polyvinyl chloride (PVC) columns to grow cotton plants. Polyvinyl chloride columns with $600 \mathrm{~mm}$ high by $150 \mathrm{~mm}$ in diameter were used to build the leaching columns (Sup. Fig.1). The inner walls of the tubes received an irregular layer of silicone and three PVC rings $(10 \mathrm{~mm})$ positioned at 150, 300 and $450 \mathrm{~mm}$ in height to reduce the preferential water flow (Sup. Fig.1). The lower end received a PVC plug with holes that allowed the percolated water to escape, which was carried by a funnel to plastic pots.

Soil samples were collected in $0.0-0.2 \mathrm{~m}$ depth in an area under pasture cultivation in Nova Odessa, state of São Paulo, Brazil. The soil was classified as Typic Hapludox (Oxisol) according to Soil Survey Staff (2014). Soil chemical attributes were determined on air-dried soil sieved with a 2-mm mesh: Total N (semi-micro Kjeldahl method) according to Cantarella and Trivelin (2001) $=673.4 \mathrm{mg} \mathrm{kg}^{-1}$ soil; $\mathrm{C} / \mathrm{N}$ relation $=17 ; \mathrm{pH}\left(0.01 \mathrm{~mol} \mathrm{~L}^{-1} \mathrm{CaCl}_{2}\right)=4.3$, available phosphorus $(\mathrm{P}$; ion exchange resin) $=6 \mathrm{mg} \mathrm{dm}^{-3}$ soil, available sulfur $\left[\mathrm{S} ; 0.01 \mathrm{~mol} \mathrm{~L}^{-1} \mathrm{Ca}\left(\mathrm{H}_{2} \mathrm{PO}_{4}\right)_{2}\right]=19 \mathrm{mg} \mathrm{dm}^{-3}$ soil, available potassium $(\mathrm{K}$; ion exchange resin $)=1.9 \mathrm{mmol}_{\mathrm{c}} \mathrm{dm}^{-3}$ soil, available calcium $(\mathrm{Ca}$; ion exchange resin $)=6 \mathrm{mmol}_{\mathrm{c}} \mathrm{dm}^{-3}$ soil, available magnesium $(\mathrm{Mg}$; ion exchange resin $)=2 \mathrm{mmol}_{\mathrm{c}}$ $\mathrm{dm}^{-3}$ soil, $\mathrm{Al}_{3}{ }^{+}\left(1 \mathrm{~mol} \mathrm{~L}^{-1} \mathrm{KCl}\right)=9 \mathrm{mmol}_{\mathrm{c}} \mathrm{dm}^{-3}$ soil, $\mathrm{H}+\mathrm{Al}(\mathrm{pH} \mathrm{SMP})=47 \mathrm{mmol}_{\mathrm{c}} \mathrm{dm}^{-3}$ soil, and soil organic matter (oxidation with $0.4 \mathrm{NK}_{2} \mathrm{Cr}_{2} \mathrm{O}_{7}$ ) $=20 \mathrm{~g} \mathrm{~kg}^{-1}$ soil. Soil granulometric composition was also determined, following Embrapa (2017) methodology: $405 \mathrm{~g} \mathrm{~kg}^{-1}$ of sand, $145 \mathrm{~g} \mathrm{~kg}^{-1}$ of silt and $450 \mathrm{~g} \mathrm{~kg}^{-1}$ of clay.

Calcium and $\mathrm{Mg}$ carbonate was applied into the soil 30 days before the beginning of the study to increase the base saturation to $70 \%$ and the $\mathrm{Mg}$ content to $8 \mathrm{mmol}_{\mathrm{c}} \mathrm{dm}^{-3}$ (Silva and Raij, 1996). Initial fertilization described in Sup. Table 1 was performed according to Rosolem et al. (2003) and Malavolta (1980). All fertilizers were mixed into the soil, with subsequent wetting at about $20 \%$ of the water-holding capacity. 
The soil was placed on the leaching columns; each column received exactly $12 \mathrm{~kg}$ of soil and $50 \mathrm{~mm}$ was left between the column surface and the soil surface. The PVC plug at the bottom end of the column received a thin layer of sand over a layer of drainage blanket to cover the water outlet holes and prevent clogging. The columns were then kept at rest for 2 weeks receiving periodic irrigations to maintain the soil wet and favor the elimination of excess $\mathrm{N}$-mineralized. During the rest period, a total of $2.5 \mathrm{~L}$ of water per column were applied. After the rest period, 10 cotton seeds (cv. Delta Opal) were sown in each column. After plant emergence, two plants per column were maintained.

The columns were irrigated weekly with sufficient volume to cause leaching and to meet the water requirement of the plants. Deionized water was applied with a drip system. Each column received a dripper with a flow rate of $2 \mathrm{~L} \mathrm{~h}^{-1}$, positioned close to the ground and in the center of the column (Sup. Fig. 1). The drip system was checked periodically to ensure homogeneous flow in all drippers. During the cotton cycle, each column received 22.3 L of water.

The leachate extracts were collected exactly one day after irrigation, the volume of extracts was measured, and sulfuric acid (1\% v/v) was added for conservation. The extract was stored in plastic bottles kept in a cold chamber until carrying out the analysis.

\section{Experimental design and treatments}

The experiment was performed in a completely randomized design, with four replications, totaling 28 leaching columns. Treatments consisted in three $\mathrm{N}$ levels applied in side-dressing (50, 100 and $150 \mathrm{~kg} \mathrm{~N} \mathrm{ha}{ }^{-1}$ ) as ${ }^{15} \mathrm{~N}$-urea source, with or without nitrification inhibitor DMPP application. An additional treatment (absence of $\mathrm{N}$ application in side-dressing) was used as control. The DMPP rate applied was $1.0 \%$ in mass based on $\mathrm{N}$-amidic content in urea (Zerulla et al., 2001). The isotopic enrichment applied was $5 \%$ (excess of ${ }^{15} \mathrm{~N}$ atoms, for all $\mathrm{N}$ levels). The $\mathrm{N}$ application in side-dressing was split in two applications: The first was performed 20 days after emergence (DAE), applying the equivalent to one third of the $\mathrm{N}$ level. The second application was performed $40 \mathrm{DAE}$, applying two third of the $\mathrm{N}$ level. The $\mathrm{N}$ fertilizers were dissolved in deionized water $(100 \mathrm{~mL})$ and applied to the soil surface with the aid of a macropipette. 
235

236

\section{Nitrate and ammonium determination in soil and leached water}

At harvest time, the soil was collected from the columns, weighed and stored in a cold chamber until carrying out the analysis. The analyzes of nitric nitrogen $\left(\mathrm{N}-\mathrm{NO}_{3}{ }^{-}\right)$and ammonium $\left(\mathrm{N}^{-\mathrm{NH}_{4}}{ }^{+}\right)$were extracted as described by Cantarella and Trivelin (2001). The analysis of $\mathrm{NO}_{3}{ }^{-}$was carried out according to Gine et al. (1980), and $\mathrm{NH}_{4}{ }^{+}$according to Krug et al. (1979), both in flow injection system (FIA). Similarly, $\mathrm{NO}_{3}{ }^{-}$and $\mathrm{NH}_{4}{ }^{+}$extraction and determination in leached water also followed Cantarella and Trivelin (2001) methodology. In addition, $\mathrm{NO}_{3}{ }^{-}$was determined according Gine et al. (1980), and $\mathrm{NH}_{4}{ }^{+}$was determined according to Krug et al. (1979), both in FIA system.

\section{Cotton dry matter and accumulated nitrogen in plants}

At 90 DAE, cotton shoot (including cotton bolls) and root were collected, washed in deionized water and dried for $90 \mathrm{~h}$ in a forced-air oven at $60{ }^{\circ} \mathrm{C}$. Then, shoot and root dry matter (g plant ${ }^{-1}$ ) were weighed. The $\mathrm{N}$ concentration was determined following Malavolta et al. (1997) methodology, with sulfuric digestion and semi-micro Kjeldahl analysis method. The accumulated $\mathrm{N}$ in shoot and root was obtained by the product of $\mathrm{N}$ concentration in tissue and dry matter yield.

\section{Nitrogen recoveries in cotton plant and soil}

We have considered as shoot: leaf, stem and bolls; and root: the entire root system. The same samples (shoot and root, separately) used to determine shoot and root dry matter mentioned above were hand mixed and a subsample was collected to perform ${ }^{15} \mathrm{~N}$ analysis. In addition, at harvest time (90 DAE) soil samples were collected from leached columns, mixed and dried for 90 $\mathrm{h}$ in a forced-air oven at $60^{\circ} \mathrm{C}$. The subsamples (cotton shoot, root and soil) were ground to pass through a 2-mm sieve. Total $\mathrm{N}$ concentration and ${ }^{15} \mathrm{~N}$ abundance (\% in atoms) were determined according to Barrie and Prosser (1996).

The $\mathrm{N}$ percentage in plant and/or soil derived from ${ }^{15} \mathrm{~N}$ labeled fertilizer (NPDF, \%) was calculated following equation 1 :

$$
N P D F=\frac{a}{b} \times 100
$$


where: " $a$ " represents the percentage of atoms of ${ }^{15} \mathrm{~N}$ in excess in plant and/or soil;

238 " $b$ " represents the percentage of atoms of ${ }^{15} \mathrm{~N}$ in excess in ${ }^{15} \mathrm{~N}$ labeled fertilizer (Trivelin et al., 239 1994). The quantity of $\mathrm{N}$ derived from fertilizer (NDF), in mg plant ${ }^{-1}$ was calculated considering 240 NPDF and accumulated N in cotton shoot, root and soil, respectively.

The quantity of $\mathrm{N}$ in plant derived from soil and other sources (native $\mathrm{N}$ and others)

$242\left(\mathrm{NDS}, \mathrm{mg} \mathrm{plant}^{-1}\right)$ was calculated following equation 2:

243

244

$N D S=A N-N D F$

245

246

where: AN represents the accumulated $\mathrm{N}$ in cotton shoot and root and NDF is the quantity of $\mathrm{N}$ in the shoot or root derived from fertilizer.

248

The ${ }^{15} \mathrm{~N}$ recovery in plant and soil ( $\mathrm{N}$ recovery, \%) was calculated following equation

249 3:

250

251

$N$ recovery $=\frac{N P D F \times \text { Nplant or Nsoil }}{\text { Nfertilizer }} \times 100$

252

253

254

where: NPDF represents the percentage of N derived from fertilizer; "Nplant" and

255 "Nsoil" represents the total quantity of $\mathrm{N}$ in plant and soil, respectively;"Nfertilizer" represents 256 the quantity of $\mathrm{N}$-fertilizer applied (Trivelin et al., 1994).

257

258

\section{Statistical analysis}

259

The Shapiro-Wilk normality test $(p>0.05)$ and Levene's homoscedasticity test $(p>0.05)$

260 were performed in the data collected. Then a variance analysis was performed using the $\mathrm{F}$ test ( $p$

$261 \leq 0.05)$. Significant results were submitted to means comparison by using Tukey test $(p \leq 0.05)$.

262 To identify dependent variables directly related to $\mathrm{N}$ application, a Pearson correlation analysis $(p$

$263 \leq 0.05)$ was performed. All the statistical analysis was performed using $\mathrm{R}$ software (R 264 Development Core Team, 2015). To create a heatmap, the corrplot package was used, using the

265 "color" and "cor.mtest" functions to calculate the coefficients and $p$-value matrices. Asterisks were 266 added to the heatmap cells to the identification of significant correlations. 


\section{Results}

\section{Nitrogen in soil, leached water and accumulated in plant tissue}

Increased $\mathrm{N}$ levels $\left(150 \mathrm{~kg} \mathrm{~N} \mathrm{ha}^{-1}\right)$ provided greater soil $\mathrm{N}-\mathrm{NO}_{3}{ }^{-}$content compared to urea application at $50 \mathrm{~kg} \mathrm{~N} \mathrm{ha}^{-1}$, regardless of presence or absence of DMPP (Fig.1A), leading to a greater soil total $\mathrm{N}$ compared to control and application of 50 and $100 \mathrm{~kg} \mathrm{~N} \mathrm{ha}^{-1}$ (Fig. 1C). Soil N$\mathrm{NH}_{4}{ }^{+}$content was not affected by $\mathrm{N}$ levels and DMPP application (Fig. 1B).

Urea with DMPP application reduced the amount of $\mathrm{NO}_{3}^{-}$leached compared to conventional urea at medium (100 $\left.\mathrm{kg} \mathrm{N} \mathrm{ha}^{-1}\right)$ and high (150 $\left.\mathrm{kg} \mathrm{N} \mathrm{ha}^{-1}\right) \mathrm{N}$ application levels (Fig. 1D). Similar trend was verified in leached $\mathrm{NO}_{3}{ }^{-}+\mathrm{NH}_{4}{ }^{+}$(Fig. 1F), while leached $\mathrm{NH}_{4}{ }^{+}$was not affected neither by N levels nor DMPP application (Fig. 1E).

Accumulated $\mathrm{N}$ in shoot and plant (shoot + root) increased with augmenting $\mathrm{N}$ application levels (Figs. 1G and 1I). Urea with DMPP provided higher accumulated $\mathrm{N}$ in shoot compared to conventional urea at high $\mathrm{N}$ application level $\left(150 \mathrm{~kg} \mathrm{~N}^{-1}\right)$ (Fig. 1G), leading to a higher plants (shoot + root) $\mathrm{N}$ accumulation (Fig. 1I). Accumulated $\mathrm{N}$ in root was higher with application of 100 and $150 \mathrm{~kg} \mathrm{~N} \mathrm{ha}^{-1}$ relative to the control and $\mathrm{N}$ level of $50 \mathrm{~kg} \mathrm{~N} \mathrm{ha}^{-1}$, regardless of presence or absence of DMPP (Fig. 1H).

\section{Nitrogen derived from fertilizer (NDF), soil and other sources (NDS) and recovery}

Nitrogen derived from fertilizer increased with augmenting $\mathrm{N}$ fertilization (Figs. 2A-C). At the highest $\mathrm{N}$ level application (150 $\left.\mathrm{kg} \mathrm{N} \mathrm{ha}^{-1}\right)$, urea with DMPP provided higher amount of NDF in shoot and plant (shoot + root) compared to conventional urea (Figs. 2A and 2C).

In general, NDS was higher with application of 100 and $150 \mathrm{~kg} \mathrm{~N} \mathrm{ha}^{-1}$ compared to control and $50 \mathrm{~kg} \mathrm{~N} \mathrm{ha}^{-1}$ application (Fig. 2D-F). Also, with application of $150 \mathrm{~kg} \mathrm{~N} \mathrm{ha}^{-1}$, urea with DMPP provided higher amount of NDS in shoot and plant (shoot + root) relative to conventional urea treatment (Figs. 2D and 2F).

Urea with DMPP provided higher $\mathrm{N}$ recovery in plant and soil compared to conventional urea, mainly at medium (100 $\left.\mathrm{kg} \mathrm{N} \mathrm{ha}^{-1}\right)$ and high (150 $\left.\mathrm{kg} \mathrm{N} \mathrm{ha}^{-1}\right) \mathrm{N}$ levels (Figs. 2G-I). 
Pearson's correlation among shoot and root dry matter and $\mathbf{N}$ in soil, leached water and plant, $\mathbf{N}$ derived from fertilizer, soil and other sources and $\mathbf{N}$ recovery in plant and soil

Pearson's correlation was positive between shoot dry matter and biomass components (root and total dry matter), $\mathrm{N}$ concentration in tissue (shoot and root $\mathrm{N}$ concentration), accumulated $\mathrm{N}$ in plant (accumulated $\mathrm{N}$ in shoot, root and shoot + root), $\mathrm{N}$ derived from fertilizer (NDF) and soil and other sources (NDS) (in shoot, root and plant), and N recovery (in plant, soil and plant + soil) (Fig. 4).

In addition, Pearson's correlation was positive between root dry matter and biomass components (shoot dry matter and total dry matter), accumulated $\mathrm{N}$ in root, $\mathrm{N}$ derived from fertilizer and soil and other sources in root and $\mathrm{N}$ recovery (in plant, soil and plant + soil) (Fig. 4).

\section{Discussion}

The application of DMPP was efficient to reduce $\mathrm{NO}_{3}{ }^{-}$leaching, leading to a greater $\mathrm{N}$ utilization by cotton plants, verified by the increased accumulated $\mathrm{N}$ in shoot and plant (shoot + root), NDF and NDS in shoot and plant (shoot + root), and recovery in plant and soil, mainly at the highest $\mathrm{N}$ level applied (150 $\mathrm{kg} \mathrm{N} \mathrm{ha}^{-1}$ ). Our results showed that under DMPP application, the amount of leached $\mathrm{NO}_{3}{ }^{-}$did not significantly differ from control treatments, regardless of $\mathrm{N}$ application level. However, at medium $\left(100 \mathrm{~kg} \mathrm{~N} \mathrm{ha}^{-1}\right)$ and high $\left(150 \mathrm{~kg} \mathrm{~N} \mathrm{ha}^{-1}\right) \mathrm{N}$ levels, urea + DMPP reduced $\mathrm{NO}_{3}{ }^{-}$leaching from 17.11 to $3.26 \mathrm{mg}$ (c.a. of $20 \%$ ) and from 33.90 to $3.70 \mathrm{mg}$ (c.a. of $11 \%$ ), respectively. Nitrification has previously stated as a two-step process involving $\mathrm{NH}_{3}$ oxidation and nitrite $\left(\mathrm{NO}_{2}{ }^{-}\right)$oxidation (Friedl et al., 2017; Luchibia et al., 2020). Ammonia oxidation to $\mathrm{NO}_{2}^{-}$is the most important step of nitrification, regulated by the amoA gene encoding the alpha subunit of the $\mathrm{NH}_{3}$ monooxygenase (AMO) within ammonia-oxidizing bacteria (AOB) and ammonia-oxidizing archaea (AOA) (Miao et al., 2019; Luchibia et al., 2020). 3,4dimethylpyrazole phosphate binds indiscriminately to membrane bound proteins including AMO, resulting in impaired growth and metabolic activity of ammonia oxidizing bacteria (AOB) (Chen et al., 2015, Florio et al., 2016; Shi et al., 2016), without affecting ammonia oxidizing archaea (Florio et al., 2014; Friedl et al., 2017).

Denitrifying enzyme activity is not directly affected by DMPP, and DMPP exerts no negative effects on abundance or activity of denitrifiers (Duan et al., 2016; Friedl et al., 2017). Excessive $\mathrm{NO}_{3}{ }^{-}$is easily lost by leaching or denitrification, which in turn reduces $\mathrm{NO}_{3}{ }^{-}$to $\mathrm{N}_{2} \mathrm{O}$ and 
finally to $\mathrm{N}_{2}$ (Friedl., et al., 2017). The reduction of $\mathrm{N}_{2} \mathrm{O}$ emissions by DMPP is therefore attributed to reduced nitrification process and a reduced $\mathrm{NO}_{3}{ }^{-}$pool available in soil for denitrification (Ruser and Schulz, 2015; Suter et al., 2020). Thus, nitrification inhibitors are substances that delay the oxidation of $\mathrm{NH}_{4}{ }^{+}$to $\mathrm{NO}_{3}{ }^{-}$, preventing $\mathrm{N}$ losses through nitrification and denitrification (Luchibia, 2020; Qiao et al., 2021), as verified in our study. This delay maintains the applied N fertilizer in the less mobile form of $\mathrm{NH}_{4}{ }^{+}$, and thereby limits the build-up of mobile $\mathrm{NO}_{3}{ }^{-}$in the soil (Friedl., et al., 2017; Padilla et al., 2018).

Urea + DMPP application associated with $150 \mathrm{~kg} \mathrm{~N}^{-1}$ provided increases of $23 \%$ in accumulated N, 27\% in NDF and 16\% in NDS in cotton plants (shoot + root) compared to conventional urea application with $150 \mathrm{~kg} \mathrm{~N} \mathrm{ha}^{-1}$. In addition, total $\mathrm{N}$ recovery (plant + soil) increased $31 \%$ when $150 \mathrm{~kg} \mathrm{~N} \mathrm{ha}^{-1}$ was applied as urea + DMPP source compared to conventional urea. Shoot and root $\mathrm{N}$ tissue concentration followed the same trend as verified in accumulated $\mathrm{N}$ in plant, with greater $\mathrm{N}$ tissue concentration with increasing $\mathrm{N}$ levels (Sup. Fig 2D and 2E). Urea + DMPP application associated with $150 \mathrm{~kg} \mathrm{~N} \mathrm{ha}^{-1}$ provided increases of $26 \%$ in shoot $\mathrm{N}$ concentration and $19 \%$ in root $\mathrm{N}$ concentration compared to conventional urea application with $150 \mathrm{~kg} \mathrm{~N} \mathrm{ha}^{-1}$. Also, the higher percentual of accumulated $\mathrm{N}$ in plant derived from fertilizer $(65 \%$ at $150 \mathrm{~kg} \mathrm{~N} \mathrm{ha}^{-1}$ application with DMPP compared to $56 \%$ at $150 \mathrm{~kg} \mathrm{~N} \mathrm{ha}^{-1}$ application with conventional urea) (Fig. 3) supports the hypothesis that the DMPP application provided greater N utilization by reducing $\mathrm{NO}_{3}{ }^{-}$leaching, increasing $\mathrm{N}$ accumulation and $\mathrm{N}$-recovery in cotton plants. Our findings suggest that the positive effect of DMPP application is more evident when high $\mathrm{N}$ levels are applied (above $100 \mathrm{~kg} \mathrm{~N} \mathrm{ha}^{-1}$ ). Similarly, DMPP applied with mineral $\mathrm{N}$ fertilizer has been reported to reduce $\mathrm{N}$ losses when associated with $\mathrm{N}$ rates above $120 \mathrm{~kg} \mathrm{~N}^{-1}$ (Dougherty et al., 2016, Koci and Nelson, 2016; Luchibia et al., 2020).

Although cotton shoot and root were not greatly influenced by $\mathrm{N}$ levels and application of DMPP, control treatment provided lower plant dry matter production (a decrease of $49 \%$ compared to the average of the other treatments) (Sup. Figs.2A-C). Nitrogen is mandatory for all life process in plants (Kuypers et al., 2018). This nutrient is an important structural component of proteins, including enzymes involved in photosynthesis, growth and development, and is a central component of chlorophyll and nucleic acids (Mu and Chen et al., 2021). Hence, $\mathrm{N}$ is one of the major limiting nutrients in most ecosystems and agricultural systems (Padilla et al., 2018), which commonly contain between $0.1 \%$ and $0.6 \% \mathrm{~N}$ in the top $0.15 \mathrm{~m}$ depth, depending on the soil type 
(Cameron et al., 2013). In this sense, poor $\mathrm{N}$ application impairs cotton growth and yield, decreasing photosynthetic rate and cotton lint development (Khan et al. 2014, 2017a, b; Luo et al., 2018). It has been exhaustively reported that $\mathrm{N}$ uptake, accumulation, remobilization, pre-stored assimilates and cotton biomass are correlated with $\mathrm{N}$ fertilization (Khan et al., 2017c; Shah et al. 2017; Luo et al., 2018). Therefore, positive Pearson's correlation between shoot and root dry matter and accumulated $\mathrm{N}$ in plant and recovery in plant and soil reinforces the well-known positive effect of $\mathrm{N}$ levels in a wide range of plant species.

We verified an average increase in total $\mathrm{N}$ recovery (considering 50,100 and $150 \mathrm{~kg} \mathrm{~N} \mathrm{ha}^{-}$ ${ }^{1}$ application levels) provided by DMPP application rangingbetween $11 \%$ (low $\mathrm{N}$ application level), 15\% (average $\mathrm{N}$ application level) and 31\% (high $\mathrm{N}$ application level). Several studies have been reported reduced $\mathrm{N}$ losses with the use of enhanced-efficiency $\mathrm{N}$ fertilizers (EENF) such as DMPP ranging between 14 to 70\% (Friedl et al., 2017; Schwenke and Haigh et al., 2019; Redding et al., 2020; Suter et al., 2020). Global N recovery in annual crops has been related to vary between 30 to 50\% (Raun and Johnson, 1999; Abalos et al., 2014; Galindo et al., 2021b). This implies that 50 to $70 \%$ of all $\mathrm{N}$-fertilizer applied can be lost within the soil through volatilization and or leaching, potentially leading to a decrease in water and air quality (Omara et al., 2019). In fact, we verified total $\mathrm{N}$ recovery in plant higher than the values reported in literature, ranging between 43 to $62 \%$. This result could be explained by the low $\mathrm{NH}_{3}{ }^{+}$volatilization losses during the greenhousecontrolled cultivation, which would represent a major source of $\mathrm{N}$-urea losses. $\mathrm{Large}^{\mathrm{NH}}{ }^{+}$ volatilization losses are unlikely since the $\mathrm{N}$ fertilizers were applied diluted in water and immediately after application the soil received irrigation. Denitrification may have been significant, since the soil has always remained quite humid due to the large water volume applied to $\mathrm{N}$ leaching occurs. Therefore, our results support the hypothesis that the efficiency of nitrification inhibitor is generally higher under conditions that favor high drainage and if high inputs of $\mathrm{N}$ fertilizer are applied (Abalos et al., 2014). If losses through $\mathrm{NO}_{3}{ }^{-}$leaching are expected to be high (e.g., coarse-textured soils, irrigated systems, greenhouse-controlled cultivation), the nitrification inhibitor DMPP is an appropriate option.

\section{Implications and outlook}

Nitrogen is one of the most limiting inputs for crop yield, which makes agriculture dependent on the application of $\mathrm{N}$ fertilizers. In 2022, approximately 111.6 million tons of $\mathrm{N}$ 
fertilizers will be consumed in the world (FAO, 2019). An expressive portion of the $\mathrm{N}$ applied to soil is lost through the processes of nitrification and denitrification (Liu et al., 2016). In addition to the economic impact, these two types of $\mathrm{N}$ losses result in serious environmental impacts such as $\mathrm{N}_{2} \mathrm{O}$ emissions to the atmosphere and eutrophication of water bodies by nitrate leaching.

In this context, the use of the DMPP inhibitor, in addition to allowing significant reduction (up to $48 \%$ ) of $\mathrm{N}$ losses by the denitrification process (Yang et al. 2016), also allows to reduce $\mathrm{N}$ losses by nitrate leaching as observed in this study and confirmed by other authors (Díez-López et al., 2008; Yang et al. 2016). Consequently, crop response is favored given the higher $\mathrm{N}$ availability in the soil.

Furthermore, the potential for mitigating $\mathrm{N}$ losses through nitrate leaching could be even greater since the soil used in this study is clay loam and has a high anion exchange capacity (highly weathered soil and rich in iron oxides), which reduces the speed of the process. Thus, especially in sandy and/or less weathered soils, where $\mathrm{N}$ losses due to nitrate leaching are higher, the use of DMPP represents a promising option in both economic and environmental aspects.

\section{Conclusions}

We have demonstrated that nitrification inhibitor 3,4-dimethylpyrazole phosphate (DMPP) was efficient to improve $\mathrm{N}$ recovery from applied urea fertilizer in cotton plants and soil by reducing $\mathrm{NO}_{3}{ }^{-}$leaching, leading to enhanced $\mathrm{N}$ acquisition from fertilizer and soil and $\mathrm{N}$ accumulation in plant, mainly when high $\mathrm{N}$ levels were applied (above $100 \mathrm{~kg} \mathrm{~N} \mathrm{ha}^{-1}$ ). We found that total $\mathrm{N}$ recovery (plant + soil) increased $31 \%$ when $150 \mathrm{~kg} \mathrm{~N}^{-1}$ was applied with urea + DMPP source compared to conventional urea. The effects of DMPP application in shoot and root dry matter did not show a particularly significant difference, probably due to the relative short experimental period. Our study provides new information regarding DMPP application on N losses and utilization by cotton plants using isotopic techniques $\left({ }^{15} \mathrm{~N}\right)$. 


\section{References}

Abalos D, Jeffery S, Sanz-Cobena A, Guardia G, Vallejo A (2014) Meta-analysis of the effect of urease and nitrification inhibitors on crop productivity and nitrogen use efficiency. Agric Ecos Environ 189:136-144.

Akiyama H, Yan X, Yagi K (2010) Evaluation of effectiveness of enhanced-efficiency fertilizers as mitigation options for $\mathrm{N}_{2} \mathrm{O}$ and $\mathrm{NO}$ emissions from agricultural soils: meta-analysis. Global Change Biol 16:1837-1846.

Barrie A, Prosser SJ (1996) Automated analysis of light-element stable isotopes by isotope ratio mass spectrometry. In: Boutton TW, Yamasaki S (Eds.), Mass Spectrometry of Soils. Marcel Dekker, New York, pp. 1-46.

Bronson KF, Hunsaker DJ, Williams CF, Thorp KR, Rockholt SM, Del Grosso SJ, Venterea RT, Barnes EM (2018) Nitrogen management affects nitrous oxide emissions under varying cotton irrigation systems in the Desert Southwest, USA. J Environ Qual 47:70-78.

Cameron KC, Di HJ, Moir JL (2013) Nitrogen losses from the soil/plant system: a review. Ann Appl Biol 162:145-173.

Cantarella H, Trivelin PCO (2001) Determination of total nitrogen in soil. In: Raij B. van, Andrade JC, Cantarella H, Quaggio JA. (Eds.). Chemical analysis for fertility assessment in tropical soils (In Portuguese). Campinas: Instituto Agronômico, pp. 262-269.

Chen Q, Qi L, Bi Q, Dai P, Sun D, Sun C, Liu W, Lu L, Ni W, Lin X (2015) Comparative effects of 3,4-dimethylpyrazole phosphate (DMPP) and dicyandiamide (DCD) on ammoniaoxidizing bacteria and archaea in a vegetable soil. Appl Microbiol Biotech 99:477-487.

Dai J, Dong H (2014) Intensive cotton farming technologies in China: achievements, challenges and countermeasures. Field Crop Res 155:99-110.

Díez-López JA, Hernaiz-Algarra P, Arauzo-Sánchez M, Carrasco-Martín I (2008) Effect of a nitrification inhibitor (DMPP) on nitrate leaching and maize yield during two growing seasons. Span J Agric Res 6:294-303.

Dougherty WJ, Collins D, Van Zwieten L, Rowlings DW (2016) Nitrification (DMPP) and urease (NBPT) inhibitors had no effect on pasture yield, nitrous oxide emissions, or nitrate leaching under irrigation in a hot-dry climate. Soil Res 54:675-683.

Duan Y.-F, Kong X-W, Schramm A, Labouriau R, Eriksen J, Petersen SO (2016) Microbial N transformations and $\mathrm{N}_{2} \mathrm{O}$ emission after simulated grassland cultivation: effects of the 
nitrification inhibitor 3, 4-dimethylpyrazole phosphate (DMPP). Appl Environ Microbiol 83:e02019-16.

Embrapa (2017) Manual of soil analysis methods. Centro Nacional de Pesquisa de Solos, Rio de Janeiro, 575 p. (In Portuguese).

FAO (2019) World fertilizer trends and outlook to 2022. Rome: FAO, 40 p.

Florio A, Clark IM, Hirsch PR, Jhurreea D, Benedetti A (2014) Effects of the nitrification inhibitor 3,4-dimethylpyrazole phosphate (DMPP) on abundance and activity of ammonia oxidizers in soil. Biol Fert Soils 50:795-807.

Florio A, Maienza A, Dell'Abate MT, Stazi SR, Benedetti A (2016) Changes in the activity and abundance of the soil microbial community in response to the nitrification inhibitor 3,4dimethylpyrazole phosphate (DMPP). J Soils Sediments 16:2687-2697.

Friedl J, Scheer C, Rowlings DW, Mumford MT, Grace PR (2017) The nitrification inhibitor DMPP (3,4-dimethylpyrazole phosphate) reduces $\mathrm{N}_{2}$ emissions from intensively managed pastures in subtropical Australia Soil Biol Biochem 108:55-64.

Galindo FS, Silva EC, Pagliari PH, Fernandes GC, Rodrigues WL, Biagini ALC, Baratella EB, Silva Junior CA, Moretti Neto MJ, Silva VM, Muraoka T, Teixeira Filho MCM (2021b) Nitrogen recovery from fertilizer and use efficiency response to Bradyrhizobium sp. and Azospirillum brasilense combined with $\mathrm{N}$ rates in cowpea-wheat crop sequence. Appl Soil Ecol 157:103764.

Galindo FS, Silva EC, Pagliari PH, Fernandes GC, Rodrigues WL, Biagini ALC, Baratella EB, Silva Junior CA, Moretti Neto MJ, Muraoka T, Teixeira Filho MCM (2021a) Nitrogen use efficiency and recovery in a wheat-corn rotation under tropical savannah conditions. Nutr Cycl Agroecos. https://doi.org/10.1007/s10705-020-10115-4.

Gao J-F, Fan X-Y, Pan K-L, Li H-Y, Sun L-X (2016) Diversity, abundance and activity of ammonia-oxidizing microorganisms in fine particulate matter. Sci Rep 6:38785.

Gilsanz C, Bàez D, Misselbrook TH, Dhanoa MS, Càrdenas LM (2016) Development of emission factors and efficiency of two nitrification inhibitors, DCD and DMPP. Agric Ecosyst Environ 216:1-8.

Gine MF, Bergamin H, Zagatto EAG, Reis BF (1980) Simultaneous determination of nitrate and nitrite by flow injection analysis. Analytica Chimica Acta 114:191-197. 
Gong Y, Wu J, Vogt J, Le TB (2019) Warming reduces the increase in $\mathrm{N}_{2} \mathrm{O}$ emission under nitrogen fertilization in a boreal peatland. Sci Total Environ 664:72-78.

Herrera JM, Rubio G, Levy L, Delgado JA, Lucho-Constantino CA, Islas-Valdez S, Pellet D (2016) Emerging and established technologies to increase nitrogen use efficiency of cereals. Agron 6:25.

Huang J, Xu CC, Ridoutt BG, Wang XC, Ren PA (2017) Nitrogen and phosphorus losses and eutrophication potential associated with fertilizer application to cropland in China. $\mathbf{J}$ Cleaner Prod 159:171-179.

Huérfano X, Menéndez S, Bolaños-Benavides M-M, González-Murua C, Estavillo J-M (2019) 3,4-dimethylpyrazole phosphate (DMPP) reduces $\mathrm{N}_{2} \mathrm{O}$ emissions from a tilled grassland in the Bogotá Savanna. Agron 9:102.

Khan A, Munsif F, Akhtar K, Afridi MZ, Zahoor A, Fahad S, Ullah R, Khan FA, Din M (2014) Response of fodder maize to various levels of nitrogen and phosphorus. Am J Plant Sci 5:2323-2329.

Khan A, Najeeb U, Wang L, Tan DKY, Yang G, Munsif F, Ali S, Hafeez A (2017a) Planting density and sowing date strongly influence growth and lint yield of cotton crops. Field Crop Res 209:129-113.

Khan A, Tan DKY, Afridi MZ, Luo H, Tung SA, Ajab M, Fahad S (2017b) Nitrogen fertility and abiotic stresses management in cotton crop: a review. Environ Sci Pollut Res 24:1-16.

Khan A, Tan DKY, Munsif F, Afridi MZ, Shah F, Wei F, Fahad S, Zhou R (2017c) Nitrogen nutrition in cotton and control strategies for greenhouse gas emissions: A review. Environ Sci Pollut Res 24:23471-23487.

Koci J, Nelson P (2016) Tropical dairy pasture yield and nitrogen cycling: effect of urea application rate and a nitrification inhibitor (DMPP). Crop Pasture Sci 67:766-779.

Krug FJ, Hansen EH, Ruzicka J (1979) Determination of ammonia in low concentrations with Nessler's reagent by flow injection analysis. Analyst 104:47-54.

Kuypers MMM, Marchant HK, Kartal B (2018) The microbial nitrogen-cycling network. Nat Rev Microbiol 16:263-276.

Li P, Dong H, Zheng C, Sun M, Liu A, Wang G, Pang C (2017) Optimizing nitrogen application rate and plant density for improving cotton yield and nitrogen use efficiency in the North China Plain. Plos One 12:e0185550. 
Liu W, Yang H, Liu J, Azevedo LB, Wang X, Xu Z, Abbaspour KC, Schulin R (2016) Global assessment of nitrogen losses and trade-offs with yields from major crop cultivations. Sci Total Environ 572:526-537.

Luchibia AO, Lam SK, Suter H, Chen Q, O’Mara B, He JZ (2020) Effects of repeated applications of urea with DMPP on ammonia oxidizers, denitrifiers, and non-targeted microbial communities of an agricultural soil in Queensland, Australia. Appl Soil Ecol 147:103392.

Luo Z, Liu H, Li W, Zhao Q, Dai J, Tian L, Dong H (2018) Effects of reduced nitrogen rate on cotton yield and nitrogen use efficiency as mediated by application mode or plant density. Field Crop Res 218:150-157.

Malavolta E (1980) Elements of plant mineral nutrition (In Portuguese). Piracicaba: Agronômica Ceres, $251 \mathrm{p}$.

Malavolta E, Vitti GC, Oliveira SA (1997) Assessment of the nutritional status of plants: principles and applications (In Portuguese). 2. ed. Piracicaba: POTAFOS, 319 p.

Miao L, Yang G, Tao T, Peng Y (2019) Recent advances in nitrogen removal from landfill leachate using biological treatments - a review. J Environ Manage 235:178-185.

Mu X, Chen Y (2021) The physiological response of photosynthesis to nitrogen deficiency. Plant Physiol Biochem 158:76-82.

Omara P, Aula L, Oyebiyi F, Raun WR (2019) World cereal nitrogen use efficiency trends: review and current knowledge. Agros Geosci Environ 2:180045.

Padilla FM, Gallardo M, Manzano-Agugliaro F (2018) Global trends in nitrate leaching research in the 1960-2017 period. Sci Total Environ 643: 400-413.

Qiao C, Mia S, Wang Y, Hou J, Xu B (2021) Assessing the effects of nitrification inhibitor DMPP on acidification and inorganic $\mathrm{N}$ leaching loss from tea (Camellia sinensis L.) cultivated soils with increasing urea-N rates. Sustainability 13:994.

R Core Team (2015) R: A language and environment for statistical computing. R Foundation for Statistical Computing, Vienna, Austria. https://www.R-project.org/.

Raun WR, Johnson GV (1999) Improving nitrogen use efficiency for cereal production. Agron J 91:357-363.

Redding MR, Phillips I, Pratt C, Paungfoo-Lonhienne C, Levett I, Hill J, Mehta C, Bailey T, Brackin R, McAuley J, Pratt S, Laycock B, Mayer DG (2020) Can nitrogen source and 
nitrification inhibitors affect in-season nitrogen supply? Comm Soil Sci Plant Anal 51: 2189-2204.

Rose TJ, Wood RH, Rose MT, Van Zwieten L (2018) A re-evaluation of the agronomic effectiveness of the nitrification inhibitors DCD and DMPP and the urease inhibitor NBPT Agr Ecosyst Environ 252:69-73.

Rosolem CA, Foloni JSS, Oliveira RH (2003) Nitrogen dynamics in soil as affected by liming and nitrogen fertilization, with straw on the soil surface (In Portuguese, with abstract in English). Pesq Agropec Bras 38:301-309.

Ruser R, Schulz R (2015) The effect of nitrification inhibitors on the nitrous oxide $\left(\mathrm{N}_{2} \mathrm{O}\right)$ release from agricultural soils-a review. J Plant Nutr Soil Sci 178:171-188.

Schwenke GD, Haigh BM (2019) Urea-induced nitrous oxide emissions under sub-tropical rainfed sorghum and sunflower were nullified by DMPP, partially mitigated by polymer-coated urea, or enhanced by a blend of urea and polymer-coated urea. Soil Res 57:342-356.

Shah AN, Yang G, Tanveer M, Iqbal J (2017) Leaf gas exchange, source-sink relationship, and growth response of cotton to the interactive effects of nitrogen rate and planting density Acta Physiol Plant 39:119.

Shi X, Hu H-W, Müller C, He J-Z, Chen D, Suter HC (2016) Effects of the nitrification inhibitor 3,4-dimethylpyrazole phosphate on nitrification and nitrifiers in two contrasting agricultural soils. Appl Environ Microbiol 82:5236-5248.

Silva NM, Raij B van (1996) Fibrous crops. In: Raij B van, Cantarella H, Quaggio JA, Furlani A MC. (Eds.). Fertilization and liming recommendation for the state of São Paulo (In Portuguese). Campinas: Instituto Agronômico. (Boletim técnico, 100).

Soil Survey Staff (2014) Keys to soil taxonomy, twelfh ed. USDA. Natural Resources Conservation Service, Washington, DC.

Suter H, Lam SK, Walker C, Chen D (2020) Enhanced efficiency fertilisers reduce nitrous oxide emissions and improve fertiliser ${ }^{15} \mathrm{~N}$ recovery in a Southern Australian pasture. Sci Total Environ 699:134147.

Trivelin PCO, Lara Cabezas WAR, Victoria RL, Reichardt K (1994) Evaluation of a ${ }^{15} \mathrm{~N}$ plot design for estimating plant recovery of fertilizer nitrogen applied to sugarcane. Scientia Agricola 51:226-234. 
571 Yang GZ, Chu KY, Tang HY, Nie YC, Zhang XL (2013) Fertilizer ${ }^{15} \mathrm{~N}$ accumulation, recovery 572 and distribution in cotton plant as affected by $\mathrm{N}$ rate and split. J Int Agric 12:999-1007.

573 Yang M, Fang Y, Sun D, Shi Y (2016) Efficiency of two nitrification inhibitors (dicyandiamide 574 and 3, 4-dimethypyrazole phosphate) on soil nitrogen transformations and plant 575 productivity: a meta-analysis. Sci Rep 6:22075.

576 Zerulla W, Barth T, Dressel J, Erhardt K, von Locquenghien KH, Pasda G, Radle M, Wissemeier 577 578 579 580 581 582 583 584 585 586 587 588 589 590 591 592 593 594 595 596 597 598 599 600 601 


\section{Figure Captions}

603

604 Figure 1. Nitrate $\left(\mathrm{NO}_{3}^{-}\right)(\mathrm{A})$, ammonium $\left(\mathrm{NH}_{4}^{+}\right)(\mathrm{B})$ and total $\mathrm{N}(\mathrm{C})$ content in soil, $\mathrm{NO}_{3}^{-}$(D), $605 \mathrm{NH}_{4}{ }^{+}(\mathrm{E})$ and $\mathrm{NO}_{3}{ }^{-}+\mathrm{NH}_{4}{ }^{+}(\mathrm{F})$ in leached water, accumulated $\mathrm{N}$ in shoot $(\mathrm{G})$, root $(\mathrm{H})$ and plant 606 (shoot + root) (I) as a function of $\mathrm{N}$ levels as urea or urea $+3,4$-dimethylpyrazole phosphate 607 (DMPP).

608

609 Figure 2. Nitrogen derived from fertilizer (NDF) in shoot (A), root (B) and plant (shoot + root)

610 (C), N derived from soil and other sources (NDS) in shoot (D), root (E) and plant (F), N recovery 611 in plant $(\mathrm{G})$, soil $(\mathrm{H})$ and total $\mathrm{N}$ recovery (plant + soil) (I) as a function of $\mathrm{N}$ levels as urea or urea $612+3,4$-dimethylpyrazole phosphate (DMPP).

613

614 Figure 3. Accumulated N percent derived from fertilizer (NDF) and from soil and other sources 615 (NDS) (F), as a function of $\mathrm{N}$ levels as urea or urea + 3,4-dimethylpyrazole phosphate (DMPP).

616

617 Figure 4. Heatmap showing the Pearson's correlation among the analyzed parameters from soil, 618 leached water and cotton plants in response to $\mathrm{N}$ levels as urea or urea $+3,4$-dimethylpyrazole 619 phosphate (DMPP). 
Figures
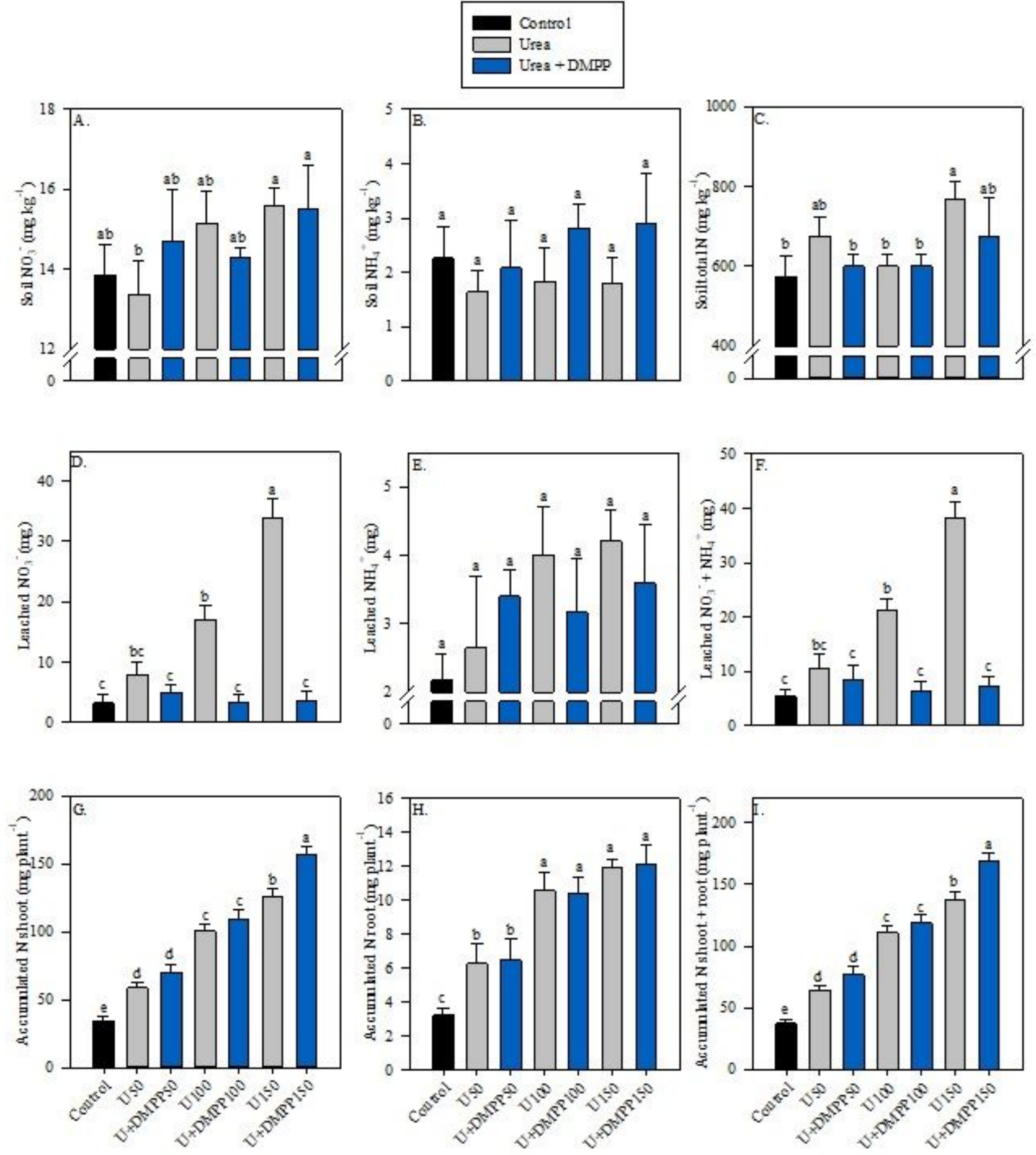

\section{Figure 1}

Nitrate (NO3-) (A), ammonium (NH4+) (B) and total N (C) content in soil, NO3- (D), NH4+ (E) and NO3- + $\mathrm{NH} 4+(F)$ in leached water, accumulated $\mathrm{N}$ in shoot $(\mathrm{G})$, root $(\mathrm{H})$ and plant (shoot + root) (I) as a function of $\mathrm{N}$ levels as urea or urea +3,4-dimethylpyrazole phosphate (DMPP). Different letters indicate significant differences between treatments according to Tukey test $(p \leq 0.05)$. Error bars indicate standard deviations 
$(n=4)$. Least significant difference [L.S.D. $(5 \%)]=1.9(A) ; 1.5(B) ; 111(C) ; 10.7(D) ; 3.1(E) ; 11.6(F) ; 13.6$ $(G) ; 2.3(H) ; 13.6(I)$.
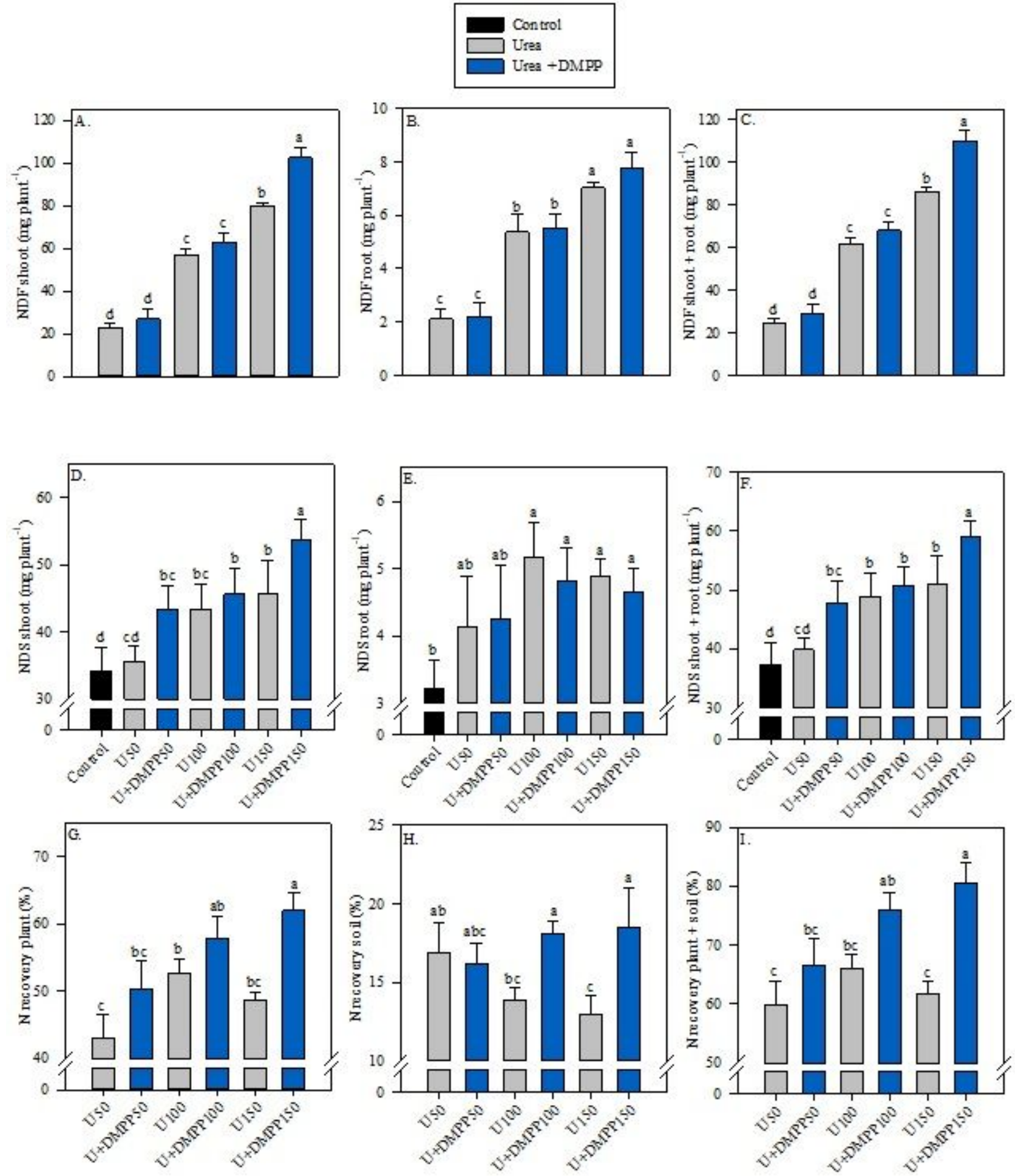

Figure 2

Nitrogen derived from fertilizer (NDF) in shoot (A), root (B) and plant (shoot + root) (C), $N$ derived from soil and other sources (NDS) in shoot (D), root (E) and plant (F), N recovery in plant $(G)$, soil $(H)$ and total $N$ recovery (plant + soil) $(\mathrm{I})$ as a function of $\mathrm{N}$ levels as urea or urea $+3,4$-dimethylpyrazole phosphate 
(DMPP). Different letters indicate significant differences between treatments according to Tukey test ( $\mathrm{p} \leq$ 0.05). Error bars indicate standard deviations $(n=4)$. Least significant difference [L.S.D. $(5 \%)]=8.3(A)$; 1.1 (B); 8.1 (C); 8.0 (D); 1.3 (E); 8.1 (F); $9.3(\mathrm{G}) ; 3.5(\mathrm{H}) ; 10.5$ (I).

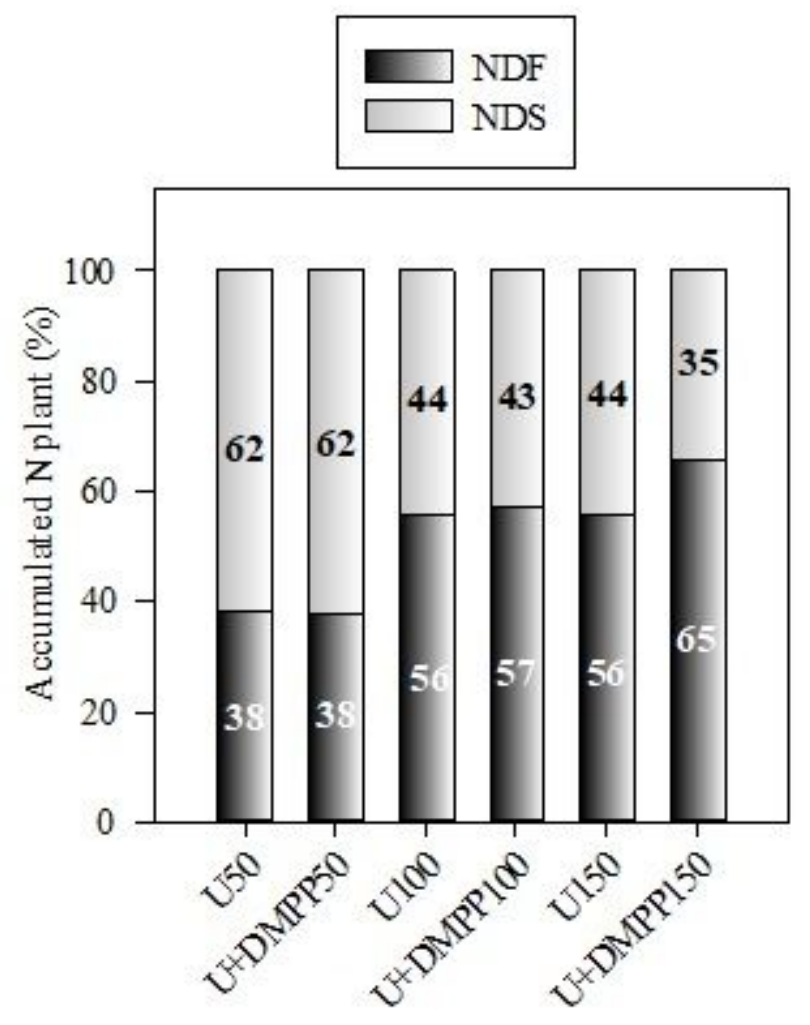

Figure 3

Accumulated $\mathrm{N}$ percent derived from fertilizer (NDF) and from soil and other sources (NDS) (F), as a function of $\mathrm{N}$ levels as urea or urea +3,4-dimethylpyrazole phosphate (DMPP). 


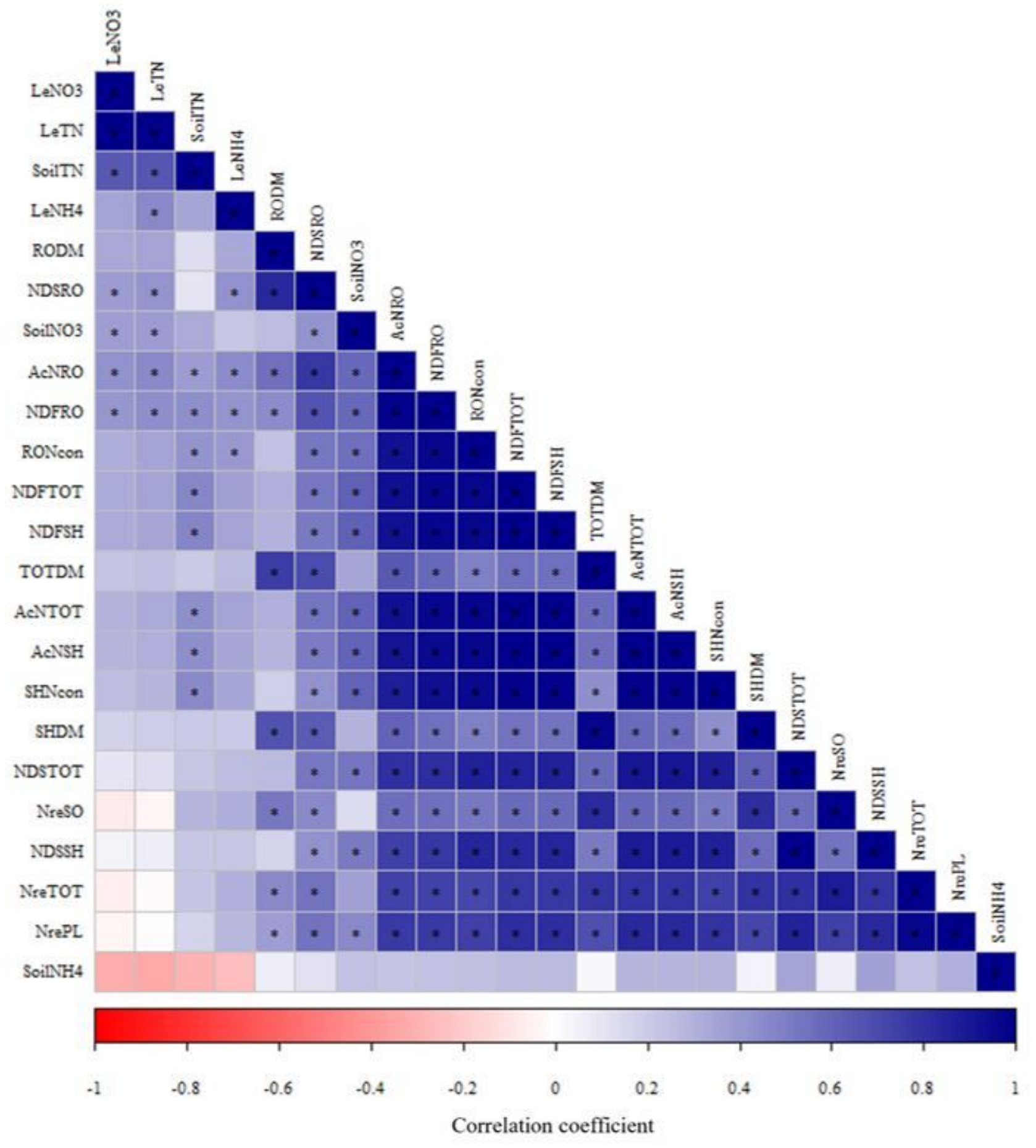

\section{Figure 4}

Heatmap showing the Pearson's correlation among the analyzed parameters from soil, leached water and cotton plants in response to $\mathrm{N}$ levels as urea or urea $+3,4$-dimethylpyrazole phosphate (DMPP). * indicates significant relationship $(\mathrm{p} \leq 0.05)$. Abbreviation: SoilNO3 $=$ NO3- content in soil, SoilNH4 $=\mathrm{NH} 4+$ content in soil, SoilTN $=$ Total $\mathrm{N}$ in soil, LeNO3 $=$ NO3- content in leached water, $\mathrm{LeNH} 4=\mathrm{NH} 4+$ content in leached water, LeTN $=$ NO3- $+\mathrm{NH} 4+$ content in leached water, SHDM = shoot dry matter, RODM = root dry matter, TOTDM = total dry matter (shoot + root), $\mathrm{SHNcon}=\mathrm{N}$ concentration in shoot, RONcon $=\mathrm{N}$ concentration in root, $\mathrm{AcNSH}=$ Accumulated $\mathrm{N}$ in shoot, $\mathrm{AcNRO}=$ Accumulated $\mathrm{N}$ in root, $\mathrm{AcNTOT}=$ 
Accumulated $\mathrm{N}$ in plant (shoot + root), $\mathrm{NDFSH}=\mathrm{N}$ derived from fertilizer in shoot, $\mathrm{NDFRO}=\mathrm{N}$ derived from fertilizer in root, NDFTOT $=\mathrm{N}$ derived from fertilizer in plant (shoot + root), $\mathrm{NDSSH}=\mathrm{N}$ derived from soil and other sources in shoot, NDSRO $=\mathrm{N}$ derived from soil and other sources in root, NDSTOT $=\mathrm{N}$ derived from soil and other sources in plant (shoot + root), $\mathrm{NrePL}=\mathrm{N}$ recovery in plant, $\mathrm{NreSO}=\mathrm{N}$ recovery in soil, NreTOT $=$ Total $\mathrm{N}$ recovery (plant + soil $)$.

\section{Supplementary Files}

This is a list of supplementary files associated with this preprint. Click to download.

- supfigsexp33321.docx 